\title{
Social Media and the New Face of Santri's Political Communication
}

\author{
Z Syarif $^{1}$ \\ Institut Agama Islam Negeri Madura, Jalan Raya Panglegur Km. 04 Pamekasan, 69371 ${ }^{1}$ \\ \{doktorzainuddinsyarif@gmail.com $\left.{ }^{1}\right\}$
}

\begin{abstract}
The world of santri is closely related to politeness and obedience to kiais or people who are considered having a great social or scientific status. The presence of technology has made it easy for the santri to access unlimited information. As a consequence, they turned into an open-minded and knowledgeable society. On the other side, the presence of technology has brought new problems because of which the new generation is no longer following the tradition of madzhab in knowledge transmission and cultural transformation. This intellectual generation no longer adopts politeness and maturity while seeing the truth claim only from others' points of view. Related to this problem, this paper is to discuss the political discourse among the santris in Pamekasan Maduraas taking place in social media related to their political attitudes. It will also explore how social media has an impact on determining the political choice of the santris. Using a qualitative approach, this paper will examine the political discourse among the santris through their social media activities such as Facebook, Whatsapp, Instagram, and others. This study found that the santri's political communication has no longer maintained politeness and obedience to the political choice of their kiais. The social media has resulted in the disappearance of politeness and obedience as shown in their activities in social media. They now become independent in their political choices.
\end{abstract}

Keywords: Social Media, Santri, Political Communication

\section{Introduction}

The presence of social media as the result of the industrial revolution 4.0 makes communication, including knowledge transmission and social and cultural transformation, more dominantly use technology services thank communication satellite and optical cable of Internet networks. Jefrry Ghannan said that digital communication technology has expanded to the extent that they promote freedom of individual expression[1, p. 8]. Easier access to information is in line with the level of curiosity among the societies to follow the news, especially on political tremors and mobilization. Mobilization, support, and political communication have also engaged the santris in political contestations like Pilbub (the election of Regents and Vice-Regents), Pileg (the legislative election) at the local, provincial and national levels, and the presidential election. The involvement of the santris is particularly pertinent in their social media accounts, such as Facebook, WhatsApp, Instagram, and other 
accounts. Those accounts are established based on the same identities, such as colleagues, working groups, teachers, alumnae, boarding schools, and certain social groups that have the same choice and preference.

Political communication in social media must contain pros and cons. It sometimes resulted in some conflicts, such as hostility, war, competition, tension, difference, discord, disagreement, inconsistency, controversy, violence, resistance, revolution, both individually and collectively[2, p. 177]. Consequently, truth claims (justification), hate speech, and prejudice against a particular group are inevitable.

The conflicts in social media among the santri's in term of political contestation is a new phenomenon since it has destroyed a well-established tradition of pesantren where modesty and obedience is maintained as a reflection of akhlaq al-karimah.

This study does not only aim to observe the students' political obedience to the political choices of their kiais within the pesantren community. Rather, it will discuss the santri's expression in social media toward the discourse of political contestation. The expression could bein the forms of support, competition, and hate speech against their friend or opposing groups.Previous researches on the similar issues have been conducted by some experts. Mohammad Khoirul Fata in his study, Membaca Polarisasi Santri dalam Kontestasi Pilpres 2019 [3], mentioned that santri's political mobilization is polarized into two pairs: Joko Widodo - Ma'ruf Amin vis a vis Prabowo Subianto - Sandiaga Uno. Fata further explained that polarization of the santri's supports to the two political pairs above leads to the contestation between two ideologies: populist Islam and nationalist Islam.Nevertheless, Fata implied that this contestation includes also some organic intellectual movements. On the one hand, NU and some traditional pesantrens affiliated with NU become the supports of JokowiMa'ruf. On the other hand, 212 movements, FPI, GNPF, Salafi pesantren, a minority of salafi santris and NU members that inclined to traditionalism or fundamentalism political ideology are on the Prabowo-Sandiaga Uno's side.

The traditionalist political ideology considers that Islam and religion is total integrity, al addin:wa al-daulah wa al-shari'ah. For them, Islam is not just a religion, but also a political and administrative power to enforce Islamic laws. This is where I have a contrastive opinion with Fata in seeing santris as data sources. I limit the terminology of santris on santri salaf/ traditional santri and students who had been contaminated by transnational Islamic movements who, in Fata's view, are closer to Hizbut-Tahrir Indonesia (HTI), Salafi, Jihadi, and Tablighis. The reason why they are selected as a data source is that the patent right of santri is originally owned by the NU and salafi (traditional Islam) and modern Islamic organizations represented by Muhammadiyah. I disagree with Fata's mapping of santri that includes transnational Islamist groups because they only seize santri from the authoritative regions of NU and Muhammadiyah through propaganda and political movements. As I mentioned earlier, these groups aim to snatch Islamic glory by winning political power and governance.

Assyari Abdullah, in his work "Membaca Komunikasi Politik Gerakan Aksi Bela Islam 212: antara Politik Identitas dan Ijtihad Alternatif" [4], illustrated that the great strength of Islam in Indonesia relies on religious organizations, i.e. NU and Muhammadiyah. However, it appears that a new power (Islamist groups)has 'entered' into these two great organizations. In my opinion, identity politics has not only infiltrated NU and Muhammadiyah, but it has also penetrated pesantrens as the learning center that gave birth Islamic leaders of NU and Muhammadiyah. The struggle for identity politics determines whether NU and Muhammadiyah will survive in Indonesia. I see that the new face of santri's political 
communication belongs to the santris who have been contaminated and hijacked by identity politics.

\section{Method}

This study is qualitative research on the political discourse among the santris through their social media activities such as Facebook, Whatsapp, Instagram, and others. The data source was santri' involvement in political mobilization discourses in online social media through their smartphone. The data analysis on the discourse of santris in social media in giving their political supports was conducted within a semiotic model, which includes three elements [5, p. 173]: field discourse, tenor discourse, and mode of discourse.

\section{Result and Discussion}

\section{Definition of Santri}

The terminology of santri has a broad meaning depending on the point of view being used. Nurcholis Madjid asserted that the term of santri derived from Sanskrit, which means 'literate'. During the era of Demak Kingdom, santris were positioned as a group of people who have a broad insight into religious knowledge and a good understanding of Arabic books. Another opinion suggested that the term santri originated from the Javanese word cantrik, which means someone who always follows his teacher.

In Clifford Geertz's theory, santris are Muslim variants other than abangan and priyayi. The principal of santri's ritual is praying five times a day according to Islamic doctrine [6, $\mathrm{p}$. 217], al-Qur'an, and Hadith. Abangan refers to a variant of society that practices lametan ritual as a form of belief [6] closer to animism and dynamism. Slametan is carried out in the request of safety and happiness to that the supernatural power [6]. Priyayi is a bureaucratic elite group that differs from abangan (mostly farmers), and santri (mostly traders). Priyayi is genealogically sourced from Hindu-Buddhist palace. The priyayi's teaching comes from three main doctrines: etiquette, art, and mysticism [6].

Ricklefs, as quoted by Fata, has a distinct outlook in defining the term santri. He said that the identity of Islam is stretching between santri and abangan [3], in which Islamic norms are melting with synthesis-mystical teachings. The identity gradually disappears along with the collapse of the Javanese kingdom because of war and the birth of Islamic educational institutions called pesantren.

I see that the term santri is originally an Indonesian term because the word does not come from Arabic countries as the center of religious knowledge transmission, except that its meaning is taken from the Arabic translation tullab. Looking at the transmission of knowledge in the early days of the Islamic education system, it turned out that similar institutions had existed before the birth of madrassah [7, p. 60], such as suffah, ribath, khan and manazil al ulama' (home's teacher). All these institutions had a student-to-teacher relationship that is similar to kiai-to-santri pattern.

The notion of santri in Madura does not exclusively belong to those students still actively studying in pesantren. The term applies also to those who have been out or graduated from their pesantrens. They feel attached morally as santris and they are recognized as santris as long as they maintain a good relationship of kiai-santri. Therefore, the santris being referred to in the data source in this study are not limited to those who are still studying or staying in their pesantrens, but also to the alumnae who are staying outside the pesantrens. 


\section{The Dynamics of Santri's Politics}

From a political perspective, santris are a source of political power due to their relation to their kiais who are so powerful. They are very obedient to their kiais. They also hold an adherence sam'an wa tă'atan, which means they will always obey their kiais in the hope of blessing from them for a better life. Consequently, it is reasonable if Olesen stated that justification of religious symbols given by santris to their kiaisin the forms of blessing and karamah [8, p. 13] and others serve as a source of political power.

Moesa in his dissertation; "Religion and Politics; Study of Kiai'sSocial of Nationalism at Post New Order," stated that santris, as one of the elements in pesantren, plays a vital role. Kiaiswithout santris are like a president without citizens. They do not only support the development of the pesantren but also sustain the kiai's influence in society [9, p. 105]. Santri, as Moesa explained, is like kiai's right hand in his representation in a political party to participate creatively in organizing state life and society [10]. Mansurnoor reinforced this idea, saying that that santris are the political anchor of kiais who play as kiai rajhe (the great religious leaders) or the elites who oversee and coordinate santris in taking a central role in societies [11, p. 183].

The Reform era has changed the mindset of society to escape from the prison of political power. The reformation wave marked a new era in political freedom. It also shifted santri's political behaviors. Formerly, the kiais were their main reference to the extent that whatever the kiai's choice is, the santris will follow it, like the slogan in the advertisement of Teh Sosro: "Apapun makanannya minumnya teh botol sostro [whatever the foods, the drink must be Teh Sosro"]. The change in the santri's political behaviors, in the perspective of democracy, is considered progress since they now can freely express their political choices according to their aspirations and conscience without being under the pressure and moral bonds of the kiais. However, the shifted political behaviors among the santris have raised an issue in terms of their bond and relation with the kiais. Santri's obedience to their kiais is not as strong as before. The kiais are no longer considered the main reference in their political decisions.

Disobedience of santris to kiais in politics, according to the theory of prismatic society, can be categorized into three types of society: fused society, prismatic society, and diffracted society. In my previous research published in Al-Tahrir and Tadris, I found that disobedience of santris to kiais in politics (for example, in the Regent Election of Pamekasan in 2008) count on two types of santri: fused and prismatic. The fused santris is divided into two models, absolute and partial obedience. In absolute obedience, the santris have a full submission to their kiais. For them, kyais are a charismatic religious leader and following kiai's political choice is a form of devotion. In partial obedience, santris obey their kiais only in terms of religious and moral aspects.As for political choice, they usually count on their personal aspiration because they realize that in politics they do not want to be prisoned by their kiai's political choice. Prismatic santris are illustrated as two transitions of political behaviors, traditional and modern. Prismatic santris see themselves independent and free from the obligation to follow their kiai's political choice. For them, a kiai is no longer regarded as the only reference in politics. At a certain point, they do not want to break away from their kiai's like a moral and religious figure.

Despite a shift in political disobedience of santris vis a vis kiais, santris still retain their kiai as a respected figure and maintain modesty in communicating with their kiais. That is,the break up from of the kiai's political choices should not be followed by hate speeches. 


\section{The New Face of Santri's Politics}

The rise of social media is characterized by the ownership of smartphones because of which the community now has more time and freedom to access unlimited information. They can now easily access anything, anytime, and anywhere. They can also freely communicate with each other via social media such as Facebook, WhatsApp, Instagram, Telegram, and other accounts. The freedom and the easier communication through the medium of smartphones have been also penetrating the social life of santri. Santris are now free to postpolitical discourse to the public through their Facebook walls. The posts and comments from santris are an interesting topic to discuss.

I identified three new faces of santri's politics based on the observation and analysis that I conducted: the first is mechanic santris, i.e. the ones who have insight and knowledge in political engagement shaped by social media (smartphone). Sometimes they are not equipped with personal and moral intelligence and, therefore, so what they got from social media is considered absolute truth. Religious leaders that that are following in their social media are attractive to them not because of their religious knowledge but also their political preferences. However, they are now transformed into a mechanic persona or robot chiefs in which they were made to reject their kiais as role models and to follow their advice, especially in political choice. The following is a thread that a santri (Anwar) posted on his Facebook regarding his preference in the political election. It was posted one day before the election of president and vice-president:

We have been certain from the beginning to vote for PAS (Prabowo-Sandiaga Uno) who are supported by the ijtima' ulama. I become more confident when Syekh Abdussomad, Sheikh Adi Hidayat, Sheikh Arifin Ilham, Syeikh Ali Jabir and all of our teachers and scholars in Madura also support them [12].

Anwar's statement by calling syeikh for his new role model indicates that he tried to give the highest respect to them, higher than his kiai who have guided him for years in pesantren. The honor call of syeikh (master teacher), as Mehdi Naskosteen said, is a respect call for a person who has the broad scientific knowledge and a very high social status [13, p. 57].

Thus, it is reasonable if Kiai Marzuki Mustamar has a concern on this group of santris for leaving their kiais as a role model. He expressed his concern in Youtube Channel which was also reposted in an Instagram account "Santri Madura"[14]. The following statement is a quote from a Youtube video uploaded in the Instagram:

It was so despotic! You throw away a kiai or teacher who has educated you (santri) for years, just because you are interested in a new one. Your kiai taught you to recite the Qur'an since you were a child. And now, you give your heart to a new person whom you just met in social media, regardless that his tahajjud, knowledge, piety and knowledge, and his daily behavior are unknown to you.

The second is santris who are, with political support, involved directly in the winning team either in the regent, legislative, or presidential elections. This group of santris is doing hegemony and counter-hegemony in battling for their powers (war of position). They are engaged in an arena of political war where all the political elites are fighting for and keeping their hegemony. These political elites are divided into incumbents and new challengers. However, they have in fact the same interests to retain and to create a new 
authority. The incumbent side is in a position to retain the hegemony, while the challenger intends to build a new power (counter-hegemony). Santris, who have involved in both sides, turn into "snipers" with social media as their shoot guns. They play character assassination with a level of understanding and religious behaviors. This strategy is called political society, which means building public opinions through hate speech in social media by searching negative aspects of both pairs in order to lead the public opinion to a certain political choice. The following is an example of a counter-hegemony using religious issues. The thread, which is a response to Neno Warisman's poet, spread easily in the WhatsApp group of pesantren" [15]:

Indeed, Neno is overreacted (lebay), again, it is from pair 02, for me, she has harassed Habaib and kiai who support Pair 01 by comparing them with Quraish disbelievers at Badar war. Then, on what basis she is worried that if Pair 02 loses, no more people will worship Allah.

She insisted in the group debate that political contestation between both parties is like between the oppressed Muslims from Madinah, i.e. Prabowo's side, and Mekkah disbelievers who are despotic and abusive, i.e. Jokowi's side. We are Indonesian citizens, Muslims or non-Muslims are not supposed to be in that position. We should be good to each other.

In contrast to the post in "Students Madura", a video is showing KH. Ma'ruf Amin, the vice-presidential candidate from Pair 01, who is visiting a charismatic kiai, i.e. Kiai Nawawi Abdul Jalil, a leader of Sidogiri pesantren, Pasuruan regency. Political mobilization by a certain group of Madurese santri is soft but it has a strong moral pressure to pesantrens and santris in the whole Madura because Kiai Nawawi Abdul Jalil is a teacher of so many great kiais in Madura's pesantrens. The status posted in the Facebook fan page of Santri Madura as follows [16]:

In the last minutes of the presidential election of 2019, some charismatic leaders with thousands of santris and alumnae in East Java have decided their votes. They are leaders of Sidogiri pesantren, Pondok shalawat Lirboyo, Bumi Shalawat, al Falah Plose, and Genggong pesantren, etc.

The political mobilization in FacebookPage "Santri Madura" is a form of support to Jokowi-Ma'ruf Amin. It was meant to be a moral invitation to santris, alumnae, and kiais in pesantrens in Madura, particularly to those who have ever been taught by the kiais mentioned in the post.

The discourse battle among the santris in social media often involves kiais as a target of hate speech for being the supporters of both parties, either the incumbent or the new challenger. Responding to this, santris who feel their kiai's dignity and authority insulted then do a counter-attack with the same insult and hate speech. One comment is posted on Facebook in which a kiai's dignity is mocked because of his support for Jokowi-Ma'ruf in the region where the pair is lost. By using improper Madurese language, the comment said [17];

In Jokowi's home, he severely lost ... it is so pityseeingMak Kaeh(Kiai)is no longer followed by his society. The Kiai only supports when he got delicacy. 
KH. Umar Hamdan Karrar posted the statement on his personal Facebook account, and it is considered an insult and humiliation to the majority of NU Muslim leaders in Madura by posting without clarification (tabayyun) to Al-Allamah KH. Mustafa Bisri, with a statement posted on his Facebook as follows [18];

Masya Allah!, how smart this person is. Until he prays for Indonesia, "Allahumma 'alaika ya Indonesia"... hey, doesn't he know the meaning of that? The meaning of that pray: "ya Allah, please destroy Indonesia!

His statement is eventually criticized by "Santri Madura" and the heads of PCNU Pamekasan Regency. KH. Taufik Hasyim [19], who concerns about it, and because of KH. Mustofa Bisri as his person of influence, he posted the following statement;

Umar Hamdan Karrar has successfully shamed Madurese people.To be honest, as Madurese santris, we are so embarrassed about his behavior!

The political mobilization that targets a kiai in social media war could be a medium to defend and to respect the kiai. However, it is sometimes also considered an effort to delegitimize and discredit the kiai's name since it may lead the opinion of the santris and alumnae to follow the kiai's political support. D. Hur Fauzi, for instance, said:

My teacher is not like your teacher who always doctrines his personal interest to his children by promising heaven for those who follow his own lusts.

The third is santris with a new ideology. This group of santri has an understanding of new ideology and Islamic understanding they learned in pesantrens that promotes Ahlu Sunnah wa al Jamaah and cultural Islam. By this new ideology, they hold a moral obligation to do jihad (Islamic striving in the path of God) in promoting what is good and preventing what is wrong. They seek to enforce Islamic shariah that is free from bid'ah and khurafat. They realize that they need a strong authority that can guarantee their intended goals. The strategy used is entering the political contestation arena under the basic principle "al-Islam al-addin wa al daulah wa shari'atuha", which is a type of traditionalist political thoughts(fundamentalism).

This type of ideology believes that religion and politics are integral and inseparable. The following is an example of a Whatsapp group chat from one of the pesantrens containing a controversial statement. It said that there is a discriminatory policy in Joko Widodo's reign in regard to the prohibition of Marxism-Communism-Leninism, and khilafah.

First, why in Jokowi's reign, there is a public official released a statement that is allowing to review Marxism and Communism but discriminatively is questioning about Islamic teachings in an Islamic government system, such as khilafah? There is also stigmatization and persecution against those who are studying about Islamic government system, khilafah (Islamic State). Second, Marxism-CommunismLeninism is contradicted with Pancasila as the fundamental principle of the state.

Communism is the main issue used in this new ideology of santris to attack the presidential candidate, Jokowi-Ma'ruf Amin versus Prabowo-Sandiaga Uno who carries the name of Islam. In other words, the santri group with this new ideology throws an issue that makes the contestation in the presidential election as a war between Communism versus 
Islam, between the foreign versus the indigenous. Other comments stated that Jokowi-Ma'ruf is in the first line to safeguard the state ideology of Pancasila and NKRI as opposed to Prabowo-Sandiaga who are strongly closer to Islamic state or khilafah. These jargons were intentionally addressed in order to legitimate the supported candidate in achieving their ultimate goal, which is to build a khilafah system in Indonesia or minimally to develop a new school (mazhab) that will replace NU and Muhammadiyah. This analysis is reasonable if we read "Suara Santri untuk Politik Alernatif", launched by a group of santri in responding to the 2019 election " [20]:

In the name of Allah, the Merciful, the Beneficent

The election day will start in days. However, we need to reach our friends, from santris, all Muslims, and Indonesian citizens in general, that like in the 2014 election, the 2019 election has not become an instrument to establish real sovereignty. In general, this is due to two things; First, the 2019 general election is participated by parties that are established or supported by the oligarchy, the capitalists and the "strong men" who have access to the government. The general election contestation is joined by the oligarchy, either directly or indirectly.

In my analysis, the group of santris with this new ideology are able to play their reformist roles through two movements, i.e. mujaddin bi al fikriyah (the reformer with thoughts) who always spread the ideas and nurture opinion of the right Islamic alternative group; andmujaddin bi al-harakah (the reformer with actions), who become the supporters and reinforcers of Indonesian political contestation and who are always ready to mobilize the masses as jihadists in religion. The dual roles of this new ideology include:firstly, they enter and strengthen the parties, as well as build a strong affiliation in political contestation with those who are regarded as having the same vision and the same ultimate goals. Secondly, they build an opinion that the general election is a grandstand for the party elites and rulers to build the economy of a particular individual or group. For this, they offer an alternative solution to meet society's expectation, i.e. a national establishment that provides welfare, equality, and social justice.

\section{Conclusion}

The rise of social media and the development of technology have made it easier for people to communicate and to access information. People also enjoy the freedom to express themselves on social media, including their engagement in political contestation. Santris, as one of the community members, plays an important role in determining the course of political contestation in which they sometimes use their social media accounts to express their political preferences. The greater impacts of social media have also shifted santri's political communication. Previously, santris tended to follow their kiai's political choice because they hold total obedience to him. However, the presence of social media has endangered the wellestablished tradition of santris. In recent times, some santris are inclined to count on their own choices rather than following their kiais as shown in their online activities in which kiais becomes the object of hate speech. From this online phenomenon, there are born three types of santris based on their behavioral shift in political choice. The first is mechanic santris who see information in social media as an absolute truth that influences their political preferences. The second is santris who have political supports by involving directly in the winning team of the candidates who run for election. The third is santris with a new ideology in which they understand that Islam and politics are integral and inseparable. They are considered as the 
reformers who sometimes call for extreme acts like jihad. Those three types of santris represent the new face of santri's political communication.

\section{References}

[1] J. Ghannam, "Social Media in the Arab World: Leading up to the Uprising of 2011," Center for International Media Assistance and National Endownment for Democracy, Washington, D.C., Feb. 2011.

[2] J. H. Turner, The Structure of Sociology Theory. Chicago: Dorsey Press, 1982.

[3] K. F. Mohamad, "Membaca Polarisasi Santri dalam Kontestasi Pilpres 2019," J. Din. Penelit., vol. 18, no. 2, pp. 325-344, 2018, doi: 10.21274/dinamika.2018.18.2.325346.

[4] A. Abdullah, "Membaca Komunikasi Politik Gerakan Aksi Bela Islam 212: Antara Politik Identitas dan Ijtihad Politik Alternatif," J. An-Nida' J. Pemikir. Islam, vol. 41, no. 2, pp. 202-212, 2017.

[5] B. Bungin, Penelitian Kualitatif, Komunikasi, Ekonomi, Kebijakan Publik, dan Ilmu Sosial Lainnya. Jakarta: Putra Grafika, 2007.

[6] C. Geertz, The Religion of Java. Canada: The Free Press of Gencoe, 1964.

[7] G. Makdisi, The Rise of Humanism in Classical Islam and the Christian West. Edinburg: Edinburgh University Press, 1990.

[8] A. Olesen, Islam and Politics in Afganistan. Church Road Richmond Surrey: Curzon Press Ltd, 1995.

[9] A. M. Moesa, "Agama dan Politik; Studi Konstruksi Sosial Kiai tentang Nasionalisme Pasca Orde Baru," Dissertation, Universitas Airlangga, Surabaya, 2006.

[10] S. H. Setyadarmodjo, "Organisasi Partai Politik dan Demokrasi," Masyarakat, Kebud. dan Polit., vol. 13, no. 1, pp. 87-94, 2000.

[11] I. A. Mansumoor, Islam in an Indonesia Word Ulama of Madura. Yogyakarta: Gadjah Mada University Press, 1990.

[12] Anwar, "Political Discourse." 2019.

[13] M. Nakosteen, History of Islamic Origin of Western Education A.D. 800-1350. Colorado: University of Colorado Press, 1964.

[14] Santrimadura, No Title. 2018.

[15] No Title. 2019.

[16] Santrimadura, No Title. 2019.

[17] "Documentation," May 2019.

[18] K. U. H. Karrar, No Title. 2015.

[19] Mei 2019. .

[20] "Suara Santri untuk Politik Alternatif" Kaum Santri Menyikapi Pemilu 2019| Arah Juang. . 